\title{
POLA PENGASUHAN DEMOKRATIS ORANG TUA DAN GAYA KEPEMIMPINAN DEMOKRATIS GURU SEBAGAI PREDIKTOR KECERDASAN EMOSIONAL SISWA
}

\author{
Abdul Saman \\ Universitas Negeri Makassar \\ Jl. A.P.Pettarani Makassar 90222 Telp. (0411) 869834 email: absan.unm@yahoo.co.id
}

\begin{abstract}
The objective of the study was to assess (1) descriptive about the students' emotional intelligence, their perception towards democratic parenting model and the teacher's democratic leadership style; (2) the correlation between the democratic parenting model with the emotional intelligence; (3) the teachers' democratic leadership style with emotional intelligence, and 4) the correlation between the democratic parenting model and the teachers' democratic leadership style with the emotional intelligence. The sample consisted of 182 student of SMA Negeri 2 Watampone, academic year 2007-2008, selected bay way of proporsional random sampling. The questionnaires to collect the data was designed to assess the perception about the democratic parenting by parents, the teachers' democratic leadership style, and the emotional intelligence. The data were analyzed by employing the Simple Regression analysis technique for hypotesis one and two, and Multiple Regression for hypotesis three. The results of the correlation indicated (1) there was a significant correlation between emotional intelligence with the perception of democratic parenting model, (2) the emotional intelligence is significantly correlated with the perception obout the teacers' democratic leadership style and (3) there was a significant correlation between the perception obout the democratic parenting model and the perception obout the teachers' democratic leadership style with emotional intelligence. The two predictors provided an effective contribution at 46 percent against the variation of criteria emotional intelligence.
\end{abstract}

Keyword: perception, emotional intelligence, parenting, leadership, democratic

\section{Pendahuluan}

Keluarga merupakan lingkungan pertama dan utama bagi anak. Pengalaman awal dalam keluarga sangat penting dalam pembentukan sikap dan perilaku anak. Keluarga merupakan tempat anak mengalami proses tumbuh kembang secara fisik, emosi, sosial, moral spiritual, dan intelektual. Melalui kehidupan keluarga, seorang anak akan belajar mengenal dirinya maupun orang lain dan kemudian lingkungan sekitarnya. Sebagai contoh, jika seorang ayah atau ibu mendidik anaknya menjadi manja (baik disadari atau tidak), maka anak akan memiliki sikap kurang percaya diri, mudah putus asa dan sulit mengerjakan sesuatu tanpa bantuan orang lain. Demikian pula, jika orang tua mendidik dengan keras, maka anak akan merasa rendah diri dan takut salah.

Salah satu tugas penting orang tua saat ini adalah mempersiapkan anaknya mengenali masalah-masalah sosial, dan emosional yang mendasar karena kecerdasan emosional seperti juga intelektualitasnya merupakan bekal keterampilan anak untuk menghadapi semua tantangan dengan cerdas, cermat, tekun, ulet, penuh tanggung jawab dan pantang menyerah. Mereka berkewajiban untuk mendorong anakanaknya menjadi cerdas, tetapi kecerdasan saja tidaklah cukup karena kecerdasan seseorang 
tidak mutlak menggambarkan seberapa jauh ia bisa sukses dalam kehidupannya tanpa disertai pengelolaan emosi yang sehat (Goleman, 1996; Farhani, I. \& Novianingtyas, I. 1997; Gottman, J. \& DeClaire, J. 1998). Karena itu, anak selain harus memiliki kecerdasan intelektual (IQ) juga dituntut mempunyai kecerdasan emosional (EQ) dan kecerdasan spiritual (SQ). Ketiga kecerdasan ini sangat penting bagi kesuksesan anak dalam menghadapi masalah dan gejolak kehidupan.

Orang tua perlu memanfaatkan sebaikbaiknya saat-saat berharga yang mereka miliki bersama anak-anaknya dengan mengambil peran aktif dan penuh makna dalam melatih mereka mengenai keterampilan hidup yang penting seperti memahami dan mengatasi perasaan yang merisaukan, mengendalikan dorongan hati dan berempati. Perilaku orang tua seperti ini digolongkan sebagai pola pengasuhan demokratis.

Tujuan dari pola pengasuhan orang tua adalah mendidik anak agar dapat menyesuaikan diri terhadap pengharapan sosial yang diinginkan masyarakat, dimana mereka mengharapkan orang tua berbuat sebaik-baiknya untuk mendidik anak sehingga setiap keluarga akan membentuk pribadi anak menjadi manusia dewasa yang diharapkan lingkungannya dan mampu mengendalikan perilakunya (Hurlock, 1968, 1978).

Kohn (1971) mengatakan bahwa pengasuhan orang tua merupakan sikap orang tua dalam berinteraksi, memberikan peraturan, hadiah maupun hukuman pada anaknya. Bentuk dan kualitas pengasuhan orang tua sangat berpengaruh terhadap pengembangan emosi dan kepribadian anak. Baumrind (1971) menyebutkan bahwa bila anak dibesarkan dalam pengasuhan yang otoriter, maka anak akan menunjukkan sikap yang tidak simpatik, tidak puas, mudah curiga, atau suka menyendiri.

Selanjutnya Hurlock (1990) menjelaskan bahwa orang tua dengan pola pengasuhan demokratis akan bersikap hangat kepada anak dalam menjalankan aturan dan disiplin, memberi kesempatan untuk berkreasi lebih maju dan mampu menghargai prestasi anak. Mengacu pada berbagai pola pengasuhan seperti yang diungkapkan banyak ahli, pola pengasuhan demokratis dipandang mampu memberikan pengaruh positif terhadap perkembangan kepribadian anak, dimana anak akan menjadi aktif dan kreatif, percaya diri, bersikap adaptif terhadap lingkungan sosial, terbuka terhadap kritik, bertanggung jawab dan mudah dalam penyesuaian diri. Anak yang dibesarkan dalam lingkungan keluarga dengan pengasuhan demokratis akan terus mengalami perkembangan yang positif baik dalam hal kecerdasannya maupun emosionalnya. Semakin demokratis orang tua dalam pengasuhan anaknya, maka kecerdasan emosionalnya juga akan meningkat.

Selain peran orang tua, kecerdasan emosional anak juga ikut ditentukan oleh sistem pendidikan formal di sekolah, dimana tidak hanya memprioritaskan pengembangan kognitif, tetapi juga memberikan porsi yang seimbang bagi pengembangan aspek afektif (emosi) dan psikomorik. Upaya ke arah ini 
Pola Pengasuhan Demokratis Orang Tua dan Gaya Kepemimpinan Demokratis Guru sebagai Prediktor Kecerdasan Emosional Siswa (Abdul Saman)

tidak dapat dilepaskan dari peran guru yang tercermin pada gaya kepemimpinannya dalam seluruh kegiatan proses belajar mengajar. Guru tidak saja dituntut untuk memberikan ilmu kepada siswa tetapi juga membantu mengelola emosi dan sosialisasi siswa agar mereka menjadi siswa yang cerdas dan sehat kehidupan emosi dan sosialnya.

Guru harus menjadi pemimpin di kelasnya. Slavin (1991), menegaskan bahwa selain guru harus menguasai materi yang akan diajarkannya, juga dituntut untuk dapat menjadi manajer kelas yang baik agar siswa tetap berada dalam momentum (gairah belajar) yang baik. Menurut Wimbarti (1997) agar pekerjaan mengelola emosi dan sosial anak dapat dijalankan dengan ringan, guru seharusnya mempunyai pengetahuan dan pengalaman keterampilan yang cukup tentang pengajaran dan perkembangan siswa, sebab dengan mengetahui perkembangan psikologis siswa, guru dengan cermat bisa mengerti bagaimana dinamika psikologis anak, bagaimana perkembangan siswa yang wajar, bagaimana penyimpangan-penyimpangan per-kembangan yang terjadi, faktor psikologis apa yang sering membuat siswa terganggu prestasi belajarnya padahal IQ-nya rata-rata atau bahkan di atas rata-rata, ke lembaga mana saja siswa akan dirujuk (direferal) bila terjadi gangguan emosi dan sosial yang serius.

Kehadiran anak di sekolah tidak hanya sekedar memenuhi tuntutan agar anak menjadi pintar tetapi lebih dari itu ia diharapkan mampu mengembangkan dan mempertahankan nilai-nilai, norma-norma dan pengetahuan yang telah diletakkan oleh orang tuanya di dalam keluarga. Agar anak dapat berkembang secara wajar, maka peran guru di sekolah harus terintegrasi dengan apa yang telah diperankan orang tuanya. Apabila terjadi perbedaan yang mencolok dalam hal perlakuan terhadap anak, maka dapat berakibat negatif dalam perkembangannya, dimana anak akan dihadapkan pada konflik pilihan nilai yang harus dijadikan sebagai acuan dalam bersikap dan berperilaku. Posisi guru sangat penting dan strategis dalam pembentukan kepribadian dan kecerdasan emosional anak.

Guru di sekolah dalam mengemban tugasnya, tidak pula terlepas dari konteks budaya yang melatarinya dan kualifikasi keilmuan yang berbeda antara satu dengan lainnya. Kondisi ini membawa konsekuensi yang tampak dari sikap dan perlakuan guru terhadap siswa baik pada saat mengajar maupun dalam setting kegiatan sekolah lainnya. Mereka diantaranya ada yang terlalu keras, ada yang biasa-biasa saja, ada yang sangat memperhatikan tuntutan kebutuhan dan karakter perkembangan siswa, tetapi ada pula yang terlalu lemah dalam menghadapi siswa. Kinerja dari masing-masing guru juga menimbulkan reaksi sikap dan perilaku yang bervariasi dari siswa.

Slavin (1991) mengemukakan bahwa guru yang menerapkan disiplin otoriter dalam mendidik anak cenderung tidak memberikan ruang gerak yang kondusif bagi perkembangan kepribadian anak bahkan anak menjadi tegang, gugup, bersikap bermusuhan dan antagonistik. Guru yang bersikap demokratis tampak 
memberikan peluang akademik kepada siswa untuk memaksimalkan kesempatan yang ada dalam mengaktualisasikan dirinya; baik guru maupun siswa dalam suasana seperti ini akan merasakan kebermaknaan dan kepuasan pada waktu dan sesudah proses pembelajaran. Selanjutnya, guru yang bergaya laissez faire cenderung membuat anak kurang bertanggung jawab, kurang menghargai aturan, egosentris dan sulit berkompetesi.

Menurut Samana (1994) gaya kepemimpinan demokratis guru dipandang ideal dan baik karena dalam segala aktivitas belajar mengajar mereka selalu mempertimbangkan pikiran-pikiran dan perasaan anak, berusaha mengenali perkembangan psikologis siswa dalam aspek fisik, intelektual, kesehatan emosi dan sosial siswa. Kondisi ini tentunya dapat menciptakan suasana belajar yang kondusif dan pengajaran yang efektif sehingga berdampak pula pada pencapaian kualitas pendidikan. Karena itu, gaya kepemimpinan demokratis guru sangat berperan bagi kecerdasan emosional siswa di sekolah.

Uraian di atas dapat disimpulkan bahwa pola pengasuhan demokratis orang tua dan gaya kepemimpinan demokratis guru merupakan salah satu faktor dominan dalam pengembangan kecerdasan emosional siswa. Karena itu, peneliti terinspirasi untuk mengkaji persepsi siswa tentang pola pengasuhan demokratis orang tua dan gaya kepemimpinan demokratis guru, dan pengaruhnya terhadap kecerdasan emosional siswa, khususnya pada siswa SMA Negeri 2 Watampone Kabupaten Bone.

\section{Metode}

Jenis penelitian ini adalah penelitian $e x$ post facto atau penelitian survei yang bersifat korelasional (Tiro, 2002). Ex-post facto karena penelitian ini akan melihat tentang pola pengasuhan yang telah dilakukan orang tua dan masih berlangsung. Demikian halnya dengan kepemimpinan guru yang telah dilakukan oleh guru dalam proses belajar mengajar dan masih berlangsung. Bersifat korelasional artinya melihat hubungan antara persepsi pola pengasuhan demokratis orangtua dan gaya kepemimpinan demokratis guru dengan kecerdasan emosional. Lokasi penelitian di SMA Negeri 2 Watampone Kabupaten Bone. Adapun sampel penelitian sebanyak 182 siswa, yang diambil melalui teknik proporsional random sampling (Sugiyono. 1999).

Penelitian ini terdiri atas dua variabel bebas yaitu (1) Persepsi pola pengasuhan demokratis orang tua (X1), dan (2) Persepsi gaya kepemimpinan demokratis guru (X2), dan satu variabel terikat yaitu kecerdasan emosional siswa (Y)

Instrumen yang digunakan untuk memperoleh data penelitian meliputi:

1. Skala persepsi pola pengasuhan demokratis orang tua (PPDOT), untuk mengungkap persepsi yang dimiliki subjek berkaitan dengan pola pengasuhan demokratis orang tuanya. Skala ini dikonstruksi sendiri mengacu pada teori Baumrind (1971) dan mengikuti model skala Likert, yang terdiri atas 5 jenjang 
Pola Pengasuhan Demokratis Orang Tua dan Gaya Kepemimpinan Demokratis Guru sebagai Prediktor Kecerdasan Emosional Siswa (Abdul Saman)

penilaian. Skala ini terdiri atas 4 dimensi atau aspek, yaitu: (1) kehangatan, (2) peraturan dan disiplin, (3) mengakui dan menghargai keberadaan anak, dan (4) hadiah dan hukuman.

2. Skala persepsi gaya kepemimpinan demokratis guru (GKDG), untuk mengukur persepsi siswa tentang perlakuan yang diterapkan oleh guru kepada siswasiswa secara demokratis dalam suasana belajar-mengajar selama berada dalam lingkungan sekolah. Skala ini mengacu pada teori yang dikemukakan oleh Claife (dalam Syah, 1995), terdiri atas 3 aspek, yaitu guru sebagai: (1) pengajar yaitu guru menguasai materi pelajaran, mengajar dengan metode yang relevan dan bervariasi dan mengevaluasi hasil belajar. (2) pendidik yaitu perhatian penuh tanpa melihat perbedaan latar belakang siswa, menghargai perbedaan dan keunggulan siswa, berkepribadian menarik, mampu menciptakan situasi belajar yang kondusif, dan konsisten me-negakkan aturan dan (3) pembimbing yaitu menunjukkan perhatian terhadap kesulitan siswa, mengarahkan siswa dan memotivasi siswa

3. Skala kecerdasan emosional siswa (KES), untuk mengukur tingkat kecerdasan emosional yang dimiliki masing-masing subjek. Skala tersebut disusun mengacu pada teori yang dikemukakan oleh Goleman (1996), terdiri atas 5 aspek, yaitu: (1) kesadaran diri dan kendali dorongan hati, (2) ketekunan, (3) semangat dan motivasi, (4) empati, dan (5) kecakapan sosial.
Data hasil penelitian dianalisis dengan menggunakan analisis regresi sederhana dan analisis regresi ganda. Analisis regresi sederhana untuk mengetahui hipotesis pertama dan kedua, sedangkan hipotesis ketiga menggunakan analisis regresi ganda. Sebelum data dianalisis terlebih dahulu dilakukan uji asumsi berupa uji normalitas dan uji linieritas (Azwar, 2000; Hadi, 2003; Slameto, 1999). Seluruh proses analisis data dilakukan dengan menggunakan bantuan program SPSS for Window versi 13,0.

\section{Hasil}

Deskripsi Hasil Penelitian

1. Deskripsi persepsi pola pengasuhan demokratis orang tua (PPDOT)

Gambaran data penelitian persepsi PPDOT memiliki rata-rata sebesar 284,97 dengan standar deviasi sebesar 8,425. Terdapat $8,79 \%$ yang memiliki persepsi PPDOT sangat tinggi, $28,57 \%$ yang memiliki persepsi PPDOT tinggi, $27,47 \%$ yang memiliki persepsi PPDOT sedang, 29,87\% yang memiliki persepsi PPDOT rendah, $5,49 \%$ yang memiliki persepsi PPDOT sangat rendah.

2. Deskripsi persepsi gaya kepemimpinan demokratis guru (GKDG)

Gambaran data penelitian GKDG memiliki rata-rata (mean) sebesar 208,45 dengan standar deviasi sebesar 10,311. Terdapat $7,14 \%$ yang memiliki GKDG sangat tinggi, 26,92\% yang memiliki GKDG tinggi, 40,66\% yang memiliki GKDG sedang, 17,03\% 
yang memiliki GKDG rendah, 8,24\% yang memiliki GKDG sangat rendah.

3. Deskripsi kecerdasan emosional siswa (KES)

Gambaran data penelitian KES memiliki rata-rata (mean) sebesar 198,02 dengan standar deviasi sebesar 8,23. Terdapat 4,95\% yang memiliki KES sangat tinggi, 35,16\% yang memiliki KES tinggi, 29,12\% yang memiliki KES sedang, $18,68 \%$ yang memiliki KES rendah, 12,09\% yang memiliki KES sangat rendah.

\section{Hasil Pengujian Hipotesis}

1. Hipotesis pertama

Hipotesis pertama dalam penelitian ini berbunyi: ada hubungan signifikan antara persepsi pola pengasuhan orang tua demokratis dengan kecerdasan emosional. Hasil uji regresi sederhana antara variabel persepsi pola pengasuhan orang tua demokratis dengan kecerdasan emosional menunjukkan korelasi (r) sebesar 0,454, dengan $\mathrm{p}=0,000(\mathrm{p}<0,01)$, dan sumbangan efektif 20,6 persen. Ini berarti kecerdasan emosional berkorelasi dengan persepsi pola pengasuhan demokratis orang tua.

2. Hipotesis kedua

Hipotesis kedua dalam penelitian ini berbunyi: ada hubungan signifikan antara gaya kepemimpinan guru demokratis dengan kecerdasan emosional. Hasil uji regresi sederhana antara variabel gaya kepemimpinan guru demokratis dengan kecerdasan emosional menunjukkan korelasi (r) sebesar 0,607 , dengan $\mathrm{p}=0,000$ $(\mathrm{p}<0,01)$, dan sumbangan efektif 36,9 persen. Ini berarti kecerdasan emosional berkorelasi dengan persepsi gaya kepemimpinan demokratis guru.

\section{Hipotesis ketiga}

Hipotesis ketiga dalam penelitian ini berbunyi: ada hubungan signifikan antara persepsi pola pengasuhan orang tua demokratis dan gaya kepemimpinan guru demokratis dengan kecerdasan emosional. Hasil uji regresi ganda antara variabel persepsi pola pengasuhan orang tua demokratis dan gaya kepemimpinan guru demokratis dengan kecerdasan emosional menunjukkan korelasi (r) sebesar 0,679, dengan $\mathrm{p}=0,000(\mathrm{p}<0,01)$, dan sumbangan efektif 46,1 persen. Ini berarti kecerdasan emosional berkorelasi dengan persepsi pola pengasuhan demokratis orang tua dan persepsi gaya kepemimpinan demokratis guru.

\section{Pembahasan}

1. Hubungan kecerdasan emosional dengan persepsi pola pengasuhan demokratis orang tua

Hipotesis pertama menyebutkan bahwa ada hubungan yang signifikan antara persepsi pola pengasuhan orang tua demokratis dengan kecerdasan emosional. Data yang diperoleh dan dianalisis dengan menggunakan regresi sederhana menunjukkan hipotesis tersebut diterima. Temuan ini dapat diartikan semakin tinggi persepsi pola 
pengasuhan orang tua demokratis semakin tinggi pula kecerdasan emosional siswa.

Hasil penelitian ini mendukung pendapat Hurlock (1978) yang mengatakan bahwa orang tua yang mempunyai sikap demokratis pada umumnya bercirikan: (a) apabila anak harus melakukan sesuatu tugas orang tua memberikan penjelasan atau alasan perlunya hal tersebut dilakukan, (b) apabila melanggar peraturan yang telah ditetapkan anak diberikan kesempatan untuk memberikan alasan mengapa ketentuan itu dilanggar sebelum anak menerima hukuman, (c) hukuman akan diberikan berkaitan dengan perbuatannya, dan (d) hadiah dan pujian diberikan oleh orang tua untuk perilaku yang diharapkan. Walgito (1993) mengungkapkan bahwa sikap demokratis orang tua mendorong terbentuknya hubungan yang harmonis dengan anak. Kontrol orang tua terhadap anak tidak berlebihan, ada dialog antara anak dengan orang tua. Karena itu antara anak dengan orang tua saling dapat bertukar pikiran, orang tua menghargai anak dan anak mempunyai respek terhadap orang tuanya. Anak dekat dengan orang tua sehingga anak tidak segan meminta nasehat kepada orang tua apabila menghadapi masalah, anak tidak merasa takut untuk berinisiatif, tidak takut akan membuat kesalahan sehingga rasa percaya dirinya akan berkembang dengan baik dan anak akan mempunyai tanggung jawab. Baumrind (1971) mengatakan bahwa dalam sikap demokratis ada sikap penghargaan dan sikap percaya orang tua terhadap anak, karenanya anak akan dapat mengembangkan potensinya dengan sebaikbaiknya.

Hasil penelitian ini juga sejalan dengan penjelasan Page (1992) bahwa individu akan menjadi lebih produktif jika mereka selalu berada dalam suasana yang demokratis daripada suasana yang otoriter. Menurutnya kondisi ini dapat tercipta karena orang tua mencoba berbagi rasa, pengalaman, diskusi dengan anak-anaknya berkaitan dengan langkah yang akan anak lakukan. Orang tua tidak menampakkan otoritas mereka dihadapan anak-anak tetapi mencoba masuk ke dalam dunia anak-anak sehingga komunikasi yang terjadi akan dapat lebih terbuka dan akrab. Lewat komunikasi seperti ini masing-masing pihak dapat saling mengetahui dan mau menerima kelebihan dan kekurangannya sehingga tidak berkembang kebiasaan untuk menyalahkan orang lain, dapat mengembangkan sikap percaya, juga sebagai sarana untuk berlatih mengemukakan ide tanpa rasa takut dan sebagainya. Cook dan Macaulay (1997) mengemukakan bahwa komunikasi yang efektif seperti ini dapat berfungsi sebagai katalisator bagi pemberdayaan anak (child empowerment).

Pemberdayaan yang dilakukan sejak dini dalam keluarga melalui pola asuh demokratis, dimana orang tua terus berupaya mengembangkan dan meningkatkan potensi yang dimiliki anak, memberikan 
dukungan yang sesuai baik yang bersifat instrumental, emosional, informasional maupun penghargaan, akan mampu membantu terbentuknya individu yang mempunyai kualitas seperti mandiri, kreatif, bertanggung jawab, jujur, sportif, dan inovatif.

Peranan orang tua sebagai model bagi keluarganya tidak dapat diabaikan bahkan sangatlah diutamakan dalam memacu perkembangan kepribadian anak. Hal ini relevan dengan penegasan Hurlock (1990) tentang sumbangan fungsi keluarga pada perkembangan anak, yaitu: (a) keluarga memberi rasa aman pada anak karena anak menjadi anggota kelompok yang stabil, (b) keluarga dapat memenuhi kebutuhan anak secara fisik maupun psikologis, (c) keluarga menjadi sumber kasih sayang dan penerimaan, tidak terpengaruh oleh apa yang dilakukan oleh anak, (d) keluarga menjadi model perilaku yang disetujui guna belajar menjadi sosial, (e) keluarga memberi bimbingan dalam pengembangan pola perilaku yang disetujui secara sosial, (f) keluarga dapat diharapkan bantuannya dalam memecahkan masalah yang dihadapi tiap anak dalam penyesuaian pada kehidupannya, (g) keluarga dapat memberi bimbingan dan bantuan dalam mempelajari kecakapan motorik, verbal dan sosial yang diperlukan untuk penyesuaian, (h) keluarga merangsang kemampuan anak untuk mencapai keberhasilan di sekolah dan kehidupan sosial, (i) keluarga membantu dalam menetapkan aspirasi yang sesuai dengan minat dan kemampuan, dan (j) keluarga menjadi sumber persahabatan hingga anak cukup besar untuk mendapatkan teman di luar rumah atau bila teman di luar rumah tidak ada.

Apabila anak dalam mempersepsikan pengasuhan orang tuanya tidak demokratis dan merasakan adanya perlakuan-perlakuan yang berten-tangan dengan perkembangan dan kebutuhan psikologisnya, maka kondisi ini akan dipersepsikan anak sebagai sesuatu yang tidak menyenangkan dan dapat menstimu-lasi berkembangnya perilakuperilaku menyimpang yang justru menjauhkan anak dari tingkatan kecerdasan emosional yang diharapkan. Penelitian Glueck \& Glueck (dalam Walkers dan Roberts, 1992) menemukan kehidupan keluarga yang kacau membuat kemungkinan 98 dari 100 anak menjadi delinkuen/kriminal atau agresif. Hal ini sejalan pula dengan pandangan teori belajar sosial seperti yang dikemukakan salah satu tokohnya yaitu Bandura (Semin \& Fiedler, 1996) bahwa perilaku merupakan perilaku yang dipelajari, dan model memainkan peranan penting dalam pembentukan suatu perilaku. Menurut pandangan teori ini, keluarga yang memiliki nilai yang berbeda dengan masyarakat luas, keluarga kurang memberi contoh tentang nilai-nilai masyarakat yang positif merupakan penyebab terjadinya perilaku agresif. Keluarga yang kurang dapat memenuhi kebutuhan psikologis anak-anaknya akan menyebabkan frustasi sehingga memung- 
Pola Pengasuhan Demokratis Orang Tua dan Gaya Kepemimpinan Demokratis Guru sebagai Prediktor Kecerdasan Emosional Siswa (Abdul Saman)

kinkan anak memunculkan perilaku agresif. Sebaliknya orang tua yang prososial akan menghasilkan anak yang berperilaku prososial.

Pendekatan Goleman dengan kecerdasan emosionalnya menunjukkan bahwa para kriminal merupakan orang-orang dengan kecerdasan emosional rendah akibat kurang mendapat perlakuan yang layak dari keluarga. Suatu penelitian (dalam Goleman, 1996) terhadap para penjahat yang melakukan tindakan paling keji dan paling brutal menemukan bahwa mereka memiliki ciri yang berbeda dengan penjahat-penjahat lain yaitu mereka hidup dari satu panti asuhan ke panti asuhan lainnya. Hal ini mengisyaratkan mereka mengalami penyianyiaan emosi yang berakibat pada tumpulnya empati yang mereka miliki. Akibat penyia-nyiaan emosi yang hebat dan terus-menerus termasuk penghinaan, perlakuan kejam dan sadis, anak akan menjadi hiper waspada akan emosi orang di sekitarnya sehingga diisyaratkan sebagai ancaman. Bukti lainnya, studi longitudinal terhadap 870 anak dari usia 8 sampai 30 tahun di New York (Goleman, 1996) menunjukkan bagaimana perilaku agresif diturunkan dari generasi ke generasi. Studi ini melaporkan bahwa anak-anak yang teridentifikasi sebagai pembuat keonaran memiliki orang tua yang mendidik mereka bukan dengan cara-cara yang demokratis, tetapi dengan kekerasan yang semena-mena dan terus-menerus mengulanginya. Cara ini menyebabkan anak memunculkan perasaan tidak berharga dan tidak berdaya, dan menjadikannya menjadi terancam dimanapun ia berada sehingga berpengaruh terhadap kecerdasan emosionalnya.

Keluarga yang di dalamnya teraplikasi prinsip-prinsip pola pengasuhan orang tua demokratis seperti memberikan kehangatan, melibatkan anak dalam pengambilan keputusan masalah-masalah keluarga atau ikut dilibatkan dalam membicarakan masalah keluarga, menerima penghargaan dari prestasinya, ada pemberian sanksi untuk kesalahan yang dilakukan anak, cenderung memberikan dukungan positif bagi perkembangan aspek psikologis anak, akan menghasilkan anak-anak dengan intra psychic strength (percaya kepada orang lain, empati, memiliki harga diri, dapat mengontrol dorongannya, mandiri, bisa dicintai dan mencintai orang lain, optimis, berani mengambil resiko, suka menolong) sehingga mereka lebih mampu menghadapi lingkungan yang kurang mendukung. Dodds (dalam Shapiro, 1997), memberikan gambaran keluarga yang menghasilkan anak dengan intrapsychic strength adalah keluarga yang mengembangkan hubungan saling mencintai dan memperhatikan, mengembangkan komunikasi dua arah, mengembangkan simbol-simbol perasaan, memberikan model dalam perilaku nurturance, empathy dan problem solving, memberikan kesempatan, melatih disiplin, memberikan dorongan dan doa, serta mengontrol perilaku anak yang mengarah ke destruktif. 
2. Hubungan kecerdasan emosional dengan persepsi gaya kepemimpinan demokratis guru

Hipotesis kedua menyebutkan bahwa ada hubungan yang signifikan antara persepsi gaya kepemimpinan guru demokratis dengan kecerdasan emosional. Data yang diperoleh dan dianalisis dengan menggunakan regresi sederhana menunjukkan hipotesis tersebut diterima. Temuan ini dapat diartikan semakin tinggi persepsi gaya kepemimpinan guru demokratis semakin tinggi pula kecerdasan emosional siswa.

Hal ini berarti sikap dan performansi guru yang merupakan manifestasi dari gaya kepemimpinannya dalam proses belajarmengajar yang dipersepsikan oleh siswasiswanya memberikan dukungan atau mempengaruhi dinamika perkembangan kecerdasan emosional siswa. Kecerdasan emo-sional siswa cenderung mengalami perubahan ditinjau dari keterlibatan guru di sekolah.

Hasil penelitian ini sejalan dengan temuan Claife (dalam Muhibbin Syah, 1995) yang menggambarkan gaya kepemimpinan guru demokratis sebagai tampilan guru yang paling baik dan ideal dibandingkan gaya kepemimpinan guru yang otoriter dan gaya kepemimpinan guru laissez-faire. Guru yang bergaya demokratis lebih suka bekerjasama dengan rekan-rekan profesinya, namun tetap menyelesai-kan tugasnya secara mandiri. Ditinjau dari sudut hasil pengajaran mereka ternyata lebih baik dan karenanya ia lebih disenangi baik oleh rekan-rekan sejawatnya maupun oleh para siswanya sendiri. Mereka lebih sering memberikan peluang akademis kepada siswa sehingga siswa-siswanya mendapat banyak kesempatan untuk mengaktualisasikan dirinya. Menurutnya suasana pendidikan yang dikendalikan dengan suasana gaya kepemimpinan demokratis akan mampu mendorong terciptanya situasi yang memberikan kebebasan kepada anak untuk memilih dan menentukan apa yang akan dipelajarinya, anak dapat belajar sesuai dengan gaya belajar yang diinginkannya sehingga mereka dapat menemukan kebebasan batin, pengenalan akan diri dan penerimaan, serta penghargaan atas kepribadiannya. Terkait dengan itu, Nasution (1982) mengemukakan guru hendaknya tetap memelihara keseimbangan antara perkembangan intelektual dan perkembangan psikologis anak. Guru yang hanya mementingkan bahan pelajaran dengan mengabaikan aspek perkembangan anak akan dapat merugikan anak. Menurutnya sikap guru hendaknya jangan terlampau bergaya otoriter atau terlampau permissive, tetapi harus lebih demokratis dan realistis karena pendidikan itu sendiri memerlukan kebebasan dan juga pengendalian. Anak-anak harus diberi kesempatan yang cukup untuk berekspresi secara bebas tanpa terlalu banyak diatur atau diawasi ketat, tetapi pada saat yang lain merekapun harus pula melakukan 
kegiatan menurut petunjuk dan di bawah pengawasan para guru.

Jabatan guru dalam situasi sosial apapun tetap dinilai oleh warga masyarakat sebagai pemberi inspirasi, penggerak, dan pelatih dalam penguasaan kecakapan tertentu bagi para siswa agar mereka siap untuk berinteraksi dengan orang lain atau siap untuk membangun hidup beserta lingkungan sosialnya. Samana (1994) mengemukakan bahwa posisi guru seperti yang dilukiskan itu hanya mungkin diwujudkan apabila guru selalu membina kompetensinya, yaitu kompetensi profesional, personal, dan sosial kemasyarakatan (Dirjen Dikdasmen, 1993). Guru yang berkompetensi tinggi akan mampu berperan sebagai pemimpin diantara kelompok siswanya dan juga diantara sesamanya, ia juga mampu berperan sebagai pendukung serta penyebar nilainilai luhur yang diyakininya dan sekaligus sebagai teladan bagi siswa dan lingkungannya. Dalam hal teknis-didaktis guru yang profesional dan bergaya demokratis mampu berperan sebagai fasilitator pengajaran, mampu mengorganisasi pengajaran secara efektif dan efesien (mampu merancang serta melaksanakan langkahlangkah pengajaran atau memandu belajar siswa secara produktif), mampu membangun motivasi belajar siswanya, mampu berperan dalam layanan bimbingan, dan sebagai penilai hasil belajar siswa demi bimbingan belajar siswa yang bersangkutan lebih lanjut. Situasi kelas atau sekolah yang kondusif sebagai manifestasi dari kepemimpinan guru demokratis ditandai oleh adanya semangat belajar/kerja yang tinggi, terarah, kooperatif, tenggang rasa, etis, efisien dan efektif.

Jelas bahwa tugas tenaga kependidikan utamanya guru semakin berat, sebab guru dituntut untuk berperan lebih dalam proses belajar-mengajar. Guru tidak saja dituntut untuk memberikan ilmu kepada siswa, tetapi juga membantu mengelola emosi dan sosialisasi siswa agar mereka menjadi siswa yang cerdas dan sehat kehidupan emosi dan sosialnya. Tuntutan ini tidaklah mudah bagi guru untuk melakukannya, apalagi guru itu dihadapkan pada tugas rutinitas mengajar yang sangat padat, dan karakteristik kepribadiannya yang kadang-kadang tidak selalu sejalan dengan karakteristik kepribadian siswa-siswanya. Situasi ini akan lebih diperparah lagi dengan minimnya pengetahuan guru tentang perkembangan psikologis anak didiknya sehingga mengurangi keterlibatannya dalam menjembatani pemenuhan kebutuhan akan perkembangan optimal siswa-siswanya. Pengakuan sejumlah siswa yang mereka tuliskan secara spontan dalam lembar jawaban dan sebagian yang langsung berceritera kepada peneliti diperoleh kesan bahwa umumnya guru di SMA Negeri 2 Watampone belum memahami secara utuh dan tidak tanggap terhadap kebutuhankebutuhan psikologis siswa yang sangat variatif di kelas, tidak menunjukkan perhatian yang menyenangkan hati dan 
menarik simpati siswa, cenderung bersikap otoriter dan tidak terbuka dalam menanggapi permasalahan siswa. Apa yang dirasakan oleh para siswa sangat mungkin mempengaruhi bentuk dan kualitas persepsinya sehingga mereka mempersepsi gaya kepemimpinan gurunya sebagai sesuatu yang tidak memberikan pengaruh terhadap kemajuan belajarnya, dan kurang mendukung berkembangnya potensipotensi kecerdasan emosionalnya.

3. Hubungan antara persepsi pola pengasuhan orang tua demoktaris dan gaya kepemimpinan guru demoktaris dengan kecerdasan emosional

Hipotesis ketiga menyebutkan bahwa ada hubungan signifikan antara persepsi pola pengasuhan orang tua demokratis dan gaya kepemimpinan guru demokratis dengan kecerdasan emosional. Data yang diperoleh dan dianalisis dengan menggunakan regresi ganda menunjukkan hipotesis tersebut diterima. Temuan ini dapat diartikan bahwa secara bersama-sama persepsi pola pengasuhan orang tua demokratis dan gaya kepemimpinan guru demokratis mempunyai hubungan yang signifikan dengan kecerdasan emosional.

Hurlock (1968) menjelaskan bahwa orang tua dengan pola pengasuhan demokratis akan bersikap hangat kepada anak dalam menjalankan aturan dan disiplin, memberi kesempatan untuk berkreasi lebih maju dan mampu menghargai prestasi anak. Mengacu pada berbagai pola pengasuhan seperti yang diungkapkan banyak ahli, pola pengasuhan demokratis dipandang mampu memberikan pengaruh positif terhadap perkembangan kepribadian anak, sehingga anak akan menjadi aktif dan kreatif, percaya diri, bersikap adaptif terhadap lingkungan sosial, terbuka terhadap kritik, bertanggung jawab dan mudah dalam penyesuaian diri. Anak yang dibesarkan dalam lingkungan keluarga dengan pengasuhan demo-kratis akan terus mengalami perkembangan yang positif baik dalam hal kecerdasannya maupun emosionalnya. Semakin demokratis orang tua dalam pengasuhan anaknya, maka kecerdasan emosionalnya juga semakin meningkat.

Hal ini menunjukkan bahwa pola pengasuhan orang tua demokratis sebagai cerminan dari kehidupan keluarga yang harmonis memperlihat-kan peran psikologis yang cukup berarti. Megawangi, dkk. (dalam Faturochman, 1997) mengemukakan peran keluarga sebagai berikut: (a) institusi pertama dan utama dalam pengembangan personal (personal growth) seperti intektual, moralitas keagamaan, kemandirian, orientasi pada prestasi dan produktivitas, (b) jaringan sosial paling kecil yang berperan sebagai arena menjalin hubungan dan arena belajar untuk mengembangkan jaringan sosial yang lebih luas bagi anak, dan (c) sistem yang mengorganisir, mengontrol dan memelihara keberlangsungan hidup keluarga. 
4. Pola pengasuhan orang tua demokratis akan memiliki sumbangan yang besar bila ditunjang dan berkaitan langsung dengan pemberdayaan pendidikan di sekolah yang salah satunya ditentukan oleh kualitas gaya kepemimpinan guru yang demokratis dalam proses belajar mengajar. Gaya kepemimpinan guru demokratis dalam penelitian ini ditentukan oleh sikap dan performansi guru yang dipersepsikan oleh siswanya berdasarkan apa yang mereka ketahui dan mereka rasakan dari perlakuan para guru yang setiap saat berinteraksi dengannya. Hal ini menunjukkan bahwa gaya kepemimpinan guru demokratis dipandang ideal dan baik karena dalam segala aktivitas belajar mengajar mereka selalu mempertimbangkan pikiran-pikiran dan perasaan anak, berusaha mengenali perkembangan psikologis siswa dalam aspek fisik, intelektual, kesehatan emosi dan sosial siswa. Kondisi ini tentunya dapat menciptakan suasana belajar yang kondusif dan pengajaran yang efektif sehingga berdampak pula pada pencapaian kualitas pendidikan. Karena itu, gaya kepemimpinan guru demokratis sangat berperan bagi kecerdasan emosional siswa di sekolah.

\section{Simpulan dan Saran}

\section{Simpulan}

Berdasarkan hasil penelitian di atas, maka dapat disimpulkan:

1. Deskripsi masing-masing variabel, meliputi:

(a) PPDOT memiliki rata-rata 284,97, standar deviasi sebesar 8,425, dan dari 182 responden, frekuensi tertinggi sebanyak 54 orang (29,87\%) mempersepsikan PPDOT rendah, (b) persepsi GKDG memiliki ratarata 208,45, standar deviasi sebesar 10,311, dan dari 182 responden, frekuensi tertinggi sebanyak 74 orang $(40,66 \%)$ mempersepsikan PPDOT sedang, dan (c) KES memiliki rata-rata 198,02, standar deviasi sebesar 8,23, dan dari 182 responden, frekuensi tertinggi sebanyak 64 orang $(35,16 \%)$ memiliki KES kategori tinggi.

2. Terdapat hubungan yang signifikan KES dengan persepsi PPDOT. Semakin positif persepsi PPDOT, semakin tinggi pula KES. Ini berarti bahwa siswa yang merasakan adanya perlakuan demokratis dari orang tuanya akan memperoleh ruang yang kondusif bagi berkembangnya potensipotensi kecerdasan emosional yang melekat pada dirinya.

3. Terdapat hubungan yang signifikan KES dengan persepsi GKDG. Semakin positif persepsi siswa tentang GKDG, semakin tinggi pula KES.

4. Terdapat hubungan yang signifikan KES dengan persepsi PPDOT dan persepsi GKDG Semakin positif persepsi siswa tentang PPDOT dan GKDG, semakin tinggi KES. Kedua prediktor tersebut dapat dipergunakan untuk memprediksi KES.

\section{Saran}

Berdasarkan simpulan hasil penelitian, maka disarankan:

1. Orang tua harusnya menerapkan pola pengasuhan yang demokratis kepada 
anaknya dalam melakukan kegiatan sebagai bibit awal berkembangnya kecerdasan emosional anak.

2. Guru sebaiknya selain sebagai pengajar juga berusaha menciptakan suasana yang menyenangkan dan memberi peluang bagi berkembangnya motivasi anak dan kecakapan sosial yang diperlukan.

3. Siswa perlu dilatih secara terus menerus untuk dapat memahami emosinya dan emosi orang lain sehingga kecakapan sosialnya dapat lebih berkembang.

\section{Daftar Pustaka}

Azwar, S. 2000. Reliabilitas dan Validitas. Yogyakarta: Pustaka Pelajar.

Baumrind, D. 1971. Current Patterns of Parental Authority. Developmental Psychology Monographs, 4, 1-103.

Farhani, I. \& Novianingtyas, I. 1997. Mempersiapkan EQ Semenjak Dini untuk Keberhasilan Berkarier di Dunia Kerja. Makalah Simposium Kongres VII ISPI. Yogyakarta, 22-25 Oktober.

Goleman, D. 1996. Kecerdasan Emosional (Penerjemah: T. Hermaya). Jakarta: Gramedia Pustaka Utama

Gottman, J. \& DeClaire, J. 1998. Kiat-kiat Membesarkan Anak yang Memiliki Kecerdasan Emosional. Jakarta: PT. Gramedia Pustaka Utama.

Hadi, S. 2003. Metode Research. Jilid II. Yogyakarta: Andi Offset

Hurlock, E. B. 1968. Developmental Psychology. New Delhi: Tata McGrawHill Publising Company, Ltd.

--------. 1978. Child Psychology. Tokyo: McGraw-Hill Publising Company, Ltd.

--------. 1990. Perkembangan Anak (terjemahan). Jakarta: Erlangga

Kohn, M. L. 1971. Social Class and Parent Child Relationship: An Interpretation Reading in Adolesent Psychology. Minesota: Burges Publising Company, Minneapolis.
Samana. 1994. Profesionalisme Keguruan. Yogyakarta: Kanisius.

Slameto, 1999. Evaluasi Pendidikan. Jakarta. Bumi Aksara.

Slavin, R. E. 1991. Educational Psychology: Theory into Practice. Englewood Cliffs, New Jersey: Prentice-Hall, Inc.

Sugiyono. 1999. Metode Penelitian Administrasi. Bandung: Alfabeta.

Syah, Muhibbin. 1995. Psikologi Pendidikan suatu Pendekatan Baru. Bandung: Remaja Rosdakarya.

Tiro, A.M. 2002. Analisis Korelasi dan Regresi. Makassar. Makassar state University Press.

Wimbarti, S. 1997. Pengelolaan Emosi Siswa di Sekolah. Makalah Seminar dalam Rangka Dies ke-48 Universitas Gadjah Mada, Yogyakarta, 13 Desember. 